\title{
Innovative Research on Higher Vocational Students Internships Practice Teaching and Management
}

\author{
Changping Song \\ Department of Mechanical Engineering, Dalian Vocational \& Technical College, Dalian, Liaoning, China \\ Lzhch11993@sina.com
}

Keywords: Higher vocational students; Internships; Teaching management; Innovation research

\begin{abstract}
The position practice is an important link in the teaching process of higher vocational education. How to carry out scientific design, reasonable arrangement, careful organization and standardized management is the key to improving the effectiveness of teaching in post-secondary practice. The article highlights the research features and innovations, and focuses on internships. The author put forward unique views and opinions, which are of guiding significance to the teaching practice and management of the internship, and also obviously promote the adaptability of the students after graduation and the smooth docking of the enterprise.
\end{abstract}

\section{The Basic Point and Main Conclusion of this Research}

The internship practice means that students in vocational colleges go out of the campus, go deep into related enterprises and institutions, and study in the real work environment while combining their professional knowledge to practice and achieve zero distance contact with future jobs. The common feature of these education methods is to closely link schools and enterprises. The purpose of these education methods is to cultivate high-quality skilled talents for enterprises.

The internship is an indispensable part of the practical teaching system in higher vocational colleges, and it is also an important teaching mode for the combination of work and study, school-enterprise cooperation, and the training of high-skilled applied talents. It strengthens the management and process monitoring of the internship, and improves the quality of personnel training. Has important significance and research value. The teaching and management of the internship is also an important measure for deepening the reform of education and teaching in higher vocational colleges, strengthening the connotation construction, and improving the quality of personnel training. It is also the reform of the combination of work and study for the training of talents, and the guidance of schools as the core and education administrative departments. The important content of the construction of teaching quality assurance system for enterprises, enterprises and society participation.

\subsection{Giving Full Play to the Role of Government Guidance and Coordination to Effectively Ensure the Full Cooperation of Schools and Enterprises.}

The government should play a role in macroeconomic regulation and guidance, and through the promotion of public opinion propaganda and policy guidance, the enterprises and schools should be encouraged to participate extensively to achieve school-enterprise cooperation in running schools and achieve a harmonious and win-win situation. Basic consensus and concerted actions should be formed. Let the whole society support and care for vocational education. At the same time, it is necessary to strengthen the government's supervision function and supervision, through policy guidance, system regulation and interest adjustment, etc., to effectively ensure the deep integration of schools and enterprises, and create a good market environment for students in vocational colleges.

The internship is a concrete embodiment of school-enterprise cooperation. It is an important part of the combination of engineering and learning talents training model. It is an important teaching link for cultivating students' comprehensive professional ability and an important way to broaden 
employment channels. Higher vocational colleges should attach great importance to the construction of extracurricular practice bases, and plan to strengthen the links with the university's majors, which have a certain scale, advanced production technology, strict management, standardized operation, and good social reputation. Cooperative partner, On the one hand, it helps students to better integrate theory with practice, further improve their professional abilities and employment competitiveness, and on the other hand prompts students to consciously recognize society and become familiar with the working atmosphere they will engage in, and consciously form a good professional quality and practical and pragmatic. Work style; Through the school-enterprise cooperation to broaden the internship channels, not only to the school related professional students to provide posts for internships, but also during the internship for the enterprise to receive internship students to lay a good foundation. As the internship stage is mainly carried out in the company's production workshop, the company's workplaces and facilities, as well as existing technical personnel, are used to provide practical guidance to internship students. Through this internship process, the problems of knowledge defects and skills shortages that occur in students' production internships can be summed up, and they can be timely and effectively reflected in the colleges so that the colleges can make further education and teaching improvements.

\subsection{Strengthen the Construction of Higher Vocational Colleges and Establish a Standardized and Scientific Mode of Practice.}

The internship is an important part of the teaching process of higher vocational education. To ensure the quality of off-campus internships, it is necessary to strengthen self-construction. In accordance with the technical requirements of the technical field and professional positions, and with reference to the relevant professional qualification standards, establish a curriculum system that emphasizes the cultivation of professional abilities, the corresponding curriculum standards, assessment standards and implementation plans, and cooperate with enterprises to develop curriculum content based on the work process, and standardize the teaching requirements. .

1) The internship practice is a comprehensive practical curriculum. Its teaching goal is to cultivate students' good professional ethics and professional skills, improve their practical work ability, develop habits of obedience and obedience, and cultivate students' awareness of cooperation and innovation. Based on the requirements of job characteristics, job skills, professional knowledge, professional literacy, etc., of various professional students, management documents concerning regulations for graduation internship internships, curriculum standards for oversight internships, assessment plans, and implementation plans shall be formulated.

2) Prepare the top job internship special task book or internship instruction book, the content should include the internship project's name, task, purpose, internship should master knowledge points and training ability points, internship arrangements and precautions, performance assessment and other content. The special task book is a design topic or paper that combines the position of internship posts and is closely related to the application of specialized core technical skills. The topics for topic design should be combined with post work, and should be determined after consultation by corporate teachers and school instructors. Students write thesis in the company. Or design the subject at any time should contact the school instructors.

3) To strengthen the organization and management of the internships, and to ensure the effective implementation of the internships, we need to establish dual-level colleges and universities, dual management institutions for university and enterprise training, establish practical training management centers, and specialize in the management of internships for all schools, and strengthen the internships. For the management, the school shall widely solicit the opinions of the cooperative enterprises, and the schools and enterprises jointly formulate and improve the management methods and related documents for the top posts practice. The internship students should sign an internship agreement with the company. The internship agreement should include the following contents: First, the name and address of the school and the internship organization, the legal representative or the person in charge, the name of the internship instructor, the internship student's name, and the professional class During the internship period, the residence address; the 
second is the internship period, internship location, internship content, and internship time; the third is rest and vacation, internship labor protection, internship remuneration, internship liability insurance, work injury insurance and other insurance, internship discipline, and internship termination conditions; The school and the internship unit think that other matters that need to be agreed. Through the signing of the agreement, the legitimate rights and interests of top students are effectively protected.

4) The examination and evaluation of top position internships shall be strictly conducted, and a handbook for the evaluation of graduation internship performance shall be established. The assessment and evaluation in the internship period shall be different from the assessment in the courses offered in the school. The evaluation subject of the top internship assessment shall be both the school and the enterprise, and both the school and the enterprise shall participate in the assessment and evaluation. Standard formulation, joint participation in evaluation implementation, guarantee of scientific evaluation and assessment, combination of qualitative assessment and quantitative assessment, combination of process assessment and result assessment, combination of practice attitude assessment and performance assessment, self-evaluation, and enterprise evaluation Combine with instructor's evaluation. We must pay particular attention to procedural evaluations, conduct process follow-up assessments on the work attitude, work discipline, and work performance of the students' internships, accumulate assessment basis materials on weekdays, and conduct comprehensive evaluations through professional skill tests to make evaluations fair and objective and avoid The uniform internship reviews, through the evaluation of the internship internship to assess students' professional skills and overall quality.

\subsection{Strengthen the Construction of Internship Instructors.}

Schools should arrange for professional teachers to go to corporate training institutions to receive training and exercise training for companies to cultivate their practical teaching ability. In the process of student internships, according to the distribution of students, the teachers are reasonably arranged to carry out practical exercises in the enterprise, and they are also responsible for the teaching tasks of teaching and management of the internships. They pay equal attention to teaching, and provide teachers and enterprises through project development and research. The opportunity for communication enhances the teachers' own scientific research capabilities so that teachers can timely understand the dual status of the company's cutting-edge technologies and instructors and engineers with practical training. This not only achieves the purpose of teachers' practice but also strengthens the students' internship period. The day-to-day management, improve the communication ability with the enterprise, can cultivate the practical professional talent for the enterprise. At the same time, it can also hire technical personnel from off-campus training bases as part-time internship instructors, and be responsible for the technical guidance for internships. The part-time teachers of the company go into the school and pass on the new technology of today to the students, so that the students can truly benefit from the integration of school-industry guidance. The advantages.

\section{The Main Features and Innovations of This Research}

In order to strengthen the teaching and management of post-secondary internships for higher vocational students and ensure the quality and effectiveness of the internship, the research group summarizes the research characteristics of the teaching and learning link for the post-secondary internship of higher vocational students as "a main line, two-way cooperation, and three Change, four combinations."

\subsection{One Main Line.}

Taking the professional ability of students' positions as the main line, taking the contents of the internship posts as the carrier, and taking the job work process as the guide to build a new model of school-enterprise cooperation. Establish a close working relationship with the company and build a platform for students' internships. 
Vocational students through the internship teaching link, complete the school and the enterprise to jointly train qualified personnel tasks. The school joint ventures cooperate in running schools and establish the teaching content for post practice under the "combination of work and study" teaching model. According to the student's internship position, together with the technical personnel of the company, the tasks based on teaching internships are jointly determined. In the internship process, the factory master and the school teacher jointly perform the teaching guidance. The internship ends with the work results, and the school and the company combine the internship results with the performance. Students' internship results are assessed. The internship includes strengthening professional capabilities, cultivating professional qualities, working attitudes, and integrating corporate management culture. Students of our school's mechanical engineering majors usually arrange for the company to perform post-placement internships at appropriate positions within six to ten months before graduation, while studying theory and practicing production practices. It is different from the practice in the traditional sense. Students who take part in the internship practice have formal jobs during the work. This is an important feature of the internship.

\subsection{The Cooperation Between the Two Parties.}

The school and the company conduct a full range of cooperation in the whole process, and put forward a long-term mechanism for the supervision, evaluation and evaluation of students jointly by the school and the enterprise. The school cooperated with the enterprise to establish a "practice teaching and management platform for post training", and formulated the "graduate graduation internship curriculum standards", "graduate internship internship management regulations", "graduation oversight internship assessment manual", "graduation internship internship plan and requirements", "Student Oversight Internship Agreement" and "School-Enterprise Cooperation" Order Class Teaching Management Approach, etc. Teaching and management documents.

\subsection{Three Transformations.}

The knowledge structure of the subject system has been transformed into a framework of production practice, the teaching model has been transformed into a teaching model integrating teaching and production, and the final examination method has been transformed into a process assessment method.

\subsection{Four Combinations.}

Combining science and technology with production practice, combining teaching content with professional qualification standards, conducting course development research according to actual production conditions of the company, designing course teaching carrier, combining learning process with work project, and standardizing student behavior The combination of corporate staff literacy. In accordance with the "combination of work and study" talent training model requirements, intensify the teaching practice and management reform of the top position.

\section{Breakthrough in the Research of This Topic}

\subsection{On-Campus Training Task "Production-Oriented".}

Based on the school-industry cooperation training base inside and outside the university, it attaches great importance to the construction of training courses, and follows the requirements of "real products, real equipment, and real environment", focusing on the arrangement and layout of professional and curriculum teaching equipment and equipment. These enterprise characteristics and product structure, type, production and other requirements, the training environment as much as possible arranged in a similar situation with the enterprise, to provide students with simulation and real enterprise environment for project training. Student training parts try to use the company's products, integrate teaching and product processing, testing, etc., arrange the difficulty of training tasks rationally, make it progressive according to the difficulty ladder, and use production-led construction ideas to train students. The students' ability to solve practical problems is to "learn" in "doing” and "doing" in "learning”, learning to do an integrated model, and completing the entire 
training content. To realize the work process of the learning process and the practical training arrangements for production.

\subsection{Enterprise Internship "Teaching".}

During the internship process for students, enterprises and schools set up some courses according to the requirements of production products. For example, Dalian Alto Robotics Class has set up courses such as "Principles and Applications of Sensors" and "Automatic Control Technology" according to the characteristics of enterprise assembly robots. The content of students' internships in the enterprise is the further extension and expansion of knowledge in these courses learned in the school. It only differs in terms of connotation and emphasis, and after the foundation of learning in the school, the top position in the enterprise is performed. During the internship process, the knowledge can be further consolidated and improved, and new ideas, breakthroughs, and innovations can be made on certain technical issues. The distance between the school and the enterprise can be shortened, and schools and enterprises can provide timely feedback and avoid weaknesses. Complement each other and jointly promote improvement. For example, in the numerical control equipment, the product is programmed and designed, and after processing, inspection and measurement, installation and debugging are performed. These are the specific teaching contents for the internship in the enterprise.

\subsection{Schools and Enterprises Guide "Double Division".}

Through the development and research of various post projects in the students' internship practice, teachers are provided with the opportunity to communicate with the company, so that teachers can timely understand the dual identity of the company's cutting-edge technology, instructors and engineers with practical training. The theoretical teachers in our school passed the internships and exams during the work process. Most of the teachers already have advanced work permits, and our school has introduced several senior engineers from the company to teach the senior engineers to enrich the teaching staff. At the same time, the company's technical staff walks into the school, passing on today's new technologies and corporate culture to students. The school's supervisors become teachers with strong teaching abilities, high technical skills, and a combination of dual-teacher teaching teams, so that students can truly benefit from the school's Guide the advantages of integration to ensure the quality of teaching internships. For example: in the inspection and measurement positions, the actual on-site teaching has cultivated the student's professional position working ability. In the practical training, the students are often arranged to conduct on-site measurement to solve the practical comprehensive problems of the production line. The company's technical staff and teachers jointly guide students to teach students in accordance with their aptitude for future jobs. At the same time, the company's technical staff and teachers form an assessment team to evaluate students' internships and cultivate their practical work ability and independent learning ability.

\subsection{Student Management "Double Conduction".}

For the management of students in the company for internships, we use a method of arranging a teacher for the school to assign an engineering technology or management personnel from the company to jointly manage the internship students. The management contents include: job production content, internship reports, weekly internships, performance assessment, daily life, etc. For this purpose, the school and the company jointly formulate an assessment and management plan.

\section{The Social Impact of the Research Results of This Project}

Through the study of teaching and management of postgraduate students in higher vocational education, the teaching mode of post practice embodies the consistency between student learning and the actual work of the company. The integration of the classroom and the practice location, the combination of the internal performance assessment and the enterprise practice assessment. It 
highlights the task-driven, project-oriented school-enterprise cooperation and the combination of vocational education and vocational education. Students who go to work have a certain influence in society and in the enterprise.

\section{Acknowledgment}

This work was supported by Dalian Vocational \& Technical College, we are indebted to the support and encouragements received from the staff and colleagues of the school of computer engineering.

\section{References}

[1] DeXian Fu. Theory of practice teaching and the cultivation of innovative spirit and ability. Journal of Hubei radio and TV University [J]. 2010,(9).

[2] Weifang Ming. Higher education operating mechanism research [M]. Beijing: People's Education Press. 2012.

[3] Zongxiang Peng. College students' innovation to create reader [M]. Shanghai, East China University of science and technology press. 2013.

[4] Shankai He. Practice the Subjective [M]. 2011.

[5] Kuang Ying, Comparision of Higher Vocational Education. Development and Change [M], Shanghai Education Press. 2016.10.

[6] Frederick E. Giesecke, Alva Mitchell, Henry C Spencer, et al. Modern Graphics Communication (Third Edition) [M]. American: Pearson Prentice Hall, 2014. 1-601 